\title{
The Relationship of Pod Colour with the Quality of Indigofera zollingeriana Seed
}

\author{
Hutasoit R, Riyadi, Juniar S \\ Indonesian Goat Research Station, PO Box 1 Sei Putih, Galang 20585, North Sumatra \\ E-mail: h.rijanto@yahoo.com
}

(received 05-10-2018; revised 18-01-2019; accepted 24-01-2019)

\begin{abstract}
ABSTRAK
Hutasoit R, Riyadi, Juniar S. 2019. Hubungan warna polong dengan kualitas benih Indigofera zollingeriana. JITV 24(1): 22-28. DOI: http://dx.doi.org/10.14334/jitv.v24i1.1923

Indigofera zollingeriana (Indigofera) berpotensi sebagai bahan pakan. Umumnya perbanyakan tanaman ini melalui benih. Kualitas benih yang rendah merupakan masalah dalam perkembangannya. Penelitian ini bertujuan untuk mengevaluasi hubungan warna polong dengan kualitas benih Indigofera. Penelitian ini dirancang dalam rancangan acak lengkap yang terdiri dari empat warna polong dan empat ulangan, yaitu: $\mathrm{P}_{1}=$ hijau, $\mathrm{P}_{2}=$ hijau kecoklatan, $\mathrm{P}_{3}=$ coklat, dan $\mathrm{P}_{4}=$ hitam. Parameter yang diamati adalah: karakteristik dan morfologi polong dan biji indigofera, pertumbuhan kecambah, dan pertumbuhan jamur pada benih indigofera. Hasil penelitian menunjukkan bahwa jumlah hama paling sedikit ditemukan di $\mathrm{P}_{2}$, polong hijau kecoklatan (14\%). jumlah benih tertinggi adalah $\mathrm{P}_{1}$, polong hijau (5173) dan $\mathrm{P}_{2}$, polong hijau kecoklatan (4944). Daya cambah tertinggi (62\%) terdeteksi di $\mathrm{P}_{2}$ (hijau kecoklatan). Tunas terberat berada di $\mathrm{P}_{2}$ pada polong hijau kecoklatan $(0,035 \mathrm{~g})$, tunas tertinggi $(2,68 \mathrm{~cm})$ terdapat pada $\mathrm{P}_{4}$ dengan polong berwarna hitam. Berdasarkan pengamatan jamur, polong hitam $\left(\mathrm{P}_{4}\right)$ memberikan hasil paling sedikit $(6,63 \%)$, namun sebagian besar jamur tumbuh sangat baik di $\mathrm{P}_{1}$ polong hijau $(47,88 \%)$. Dapat disimpulkan bahwa warna polong hijau kecoklatan adalah fase terbaik untuk panen benih I. zolligeriana berkualitas baik.
\end{abstract}

Kata Kunci: Benih Indigofera zollingeriana, Warna Polong, Germinasi, Tunas

\begin{abstract}
Hutasoit R, Riyadi, Juniar S. 2019. The relationship of pod colour with the quality of Indigofera zollingeriana. JITV 24(1): 2228. DOI: http://dx.doi.org/10.14334/jitv.v24i1.1923

Indigofera zollingeriana (Indigofera) plant is potential feed ingredients. The propagation of this plant is through seed. The low quality of seed is a problem in its development. This study was aimed to evaluate the relationship of pod colour with quality of Indigofera seeds. The study was designed in a complete randomized design consisting of four pod colours and four replications, namely: $\mathrm{P}_{1}=$ green, $\mathrm{P}_{2}=$ brownish green, $\mathrm{P}_{3}=$ brown, and $\mathrm{P}_{4}=$ black. The parameters observed were: characteristic and morphology of pods and seeds of Indigofera, the growth of sprouts, and the growth of fungus on Indigofera seed. Results showed that the number of pests was fewest found in $\mathrm{P}_{2}$, brownish green pod (14\%). The highest number of seeds was in $\mathrm{P}_{1}$, green pod (5173) and $\mathrm{P}_{2}$, brownish green pod (4944). The highest germination (62\%) was detected in $\mathrm{P}_{2}$ (brownish green). The heaviest sprout was in $\mathrm{P}_{2}$, in brownish green pod $(0.035 \mathrm{~g})$, highest sprout $(2.68 \mathrm{~cm})$ in $\mathrm{P}_{4}$, black pod colour. Based on fungus observation, the black pod $\left(\mathrm{P}_{4}\right)$ provided the fewest result $(6.63 \%)$, however most fungus grew very well in $\mathrm{P}_{1}$, the green pod $(47.88 \%)$. It could be concluded that the brownish green pod colour was the best phase for harvesting good quality $I$. zolligeriana seed.
\end{abstract}

Key Words: Indigofera zollingeriana Seed, Pods Colour, Germination, Sprout

\section{INTRODUCTION}

One of the most popular forages is Indigofera zollingeriana (Indigofera). It has very high nutrient content, is potential as feed ingredient, and is able to increase animal productivity (Salvador et al. 2010; Suharlina et al. 2016; Telleng et al. 2017). In Indonesia, the development of Indigofera has been quite good and has been spread almost throughout the provinces with various agro-ecosystems. In addition, Indigofera is also very easy to plant with seeds. The seeds are usually obtained from black pods, harvested in the field through drying and milling process to separate the seeds from the pods.

The demand of Indigofera seed is increasing every year. On the other hand, the providers can not fulfill all the demands. Low production and quality of seeds, contaminating pest and fungus on the sprouts were most likely due to the lack of harvesting management. The available information obtained by increasing Indigofera seed productivity remains limited. The previous research reported by Kissock \& Haferkampa (1983), presowing seed treatment and temperature affect germination of Indigofera miniata var leptosepala 
obtained an average sprout growth of $63 \%$. Abdullah (2014) reported percentage of indigofera seed germination was $28-35 \%$ and increased $67-74 \%$ by giving organic matter. Girsang (2012) reported that $\mathrm{CO}_{2}$ injected into the seed of Indigofera resulted in $36 \%$ germination at the $10 \%$ level of $\mathrm{CO}_{2}$. Comparing 5 different soaking temperatures, Hutasoit et al. (2017) obtained the highest sprout growth $(50 \%)$ at the $100^{\circ} \mathrm{C}$. These results could not increase the productivity of Indigofera seeds.

There were no reports on harvesting management of Indigofera seed, especially the time and characteristics of good pods to be harvested. According to our observations at the time of harvesting, there are some different colour of Indigofera pod; namely: green, brownish green, brown, and black. In the green pod, Indigofera seeds look clean from the pests and most likely good to harvest, but the seeds are still in soft and wet condition. In the brownish green pods, the seed conditions are slightly hardened, but it already shows the spot of pest attacks. In the brown pod, the seed conditions are old and hardened, but they have attacked by some pest, marked by eggs form and rotten liquids. In black colour pods, the seeds are old and pithy. Generally, the seeds were harvested at this condition. Nevertheless, many seeds in this phase were broken, hollow, have no seed meat, and have borer pest. So far, there is no information about the kind of this pest, and unknown pest species attacking the seeds. In Leucaena leucochepala, the pest, Acanthoscelides macrophthalmus caused damage of the seed (Effowe et al. 2010), resulted in 50\% of seeds could not be used. While in food crops, Etiella spp pod borer can cause damage on soybean and high damage since the larval life is very long until the age of 18 days (Ernestina 2003).

Besides the ageing plant, the pod colour is also very decisive in the harvesting of seeds in order to minimize the attacks of pests and fungi. Previous studies reported several good pod colour phases for harvesting such as yellowish brown colour on Gliricidia (Winata et al. 2012), pale brown (russet) on Calopogonium (Rahmawathi 2017), orange brown on Leucaena leucocephala (Al-Bugg 2017), reddish brown on bambara peanut (Hindun 2013), and blackish brown on soybean (Harnowo 2015).

There are only few information on pod colour of Indigofera seed to harvest. Therefore, the purpose of this research was to evaluate the relationship of pod colour with the quality of Indigofera zollingeriana seed.

\section{MATERIAL AND METHODS}

This activity was carried out in experimental field and laboratory of Indonesian Goat Research Station, Deli Serdang Regency of North Sumatera, located at an altitude of $\pm 50 \mathrm{~m}$ above sea level with an average temperature of $27^{\circ} \mathrm{C}, 70 \%$ humidity and rainfall of 1800 $\mathrm{mm} /$ year. The study was conducted from February to May 2018. The seeds of feed plant used are Indigofera zollingeriana, as many as 400 twigs of pods. This study was conducted using a Completely Randomized Design (CRD) consisting of four pod colours. Namely: $\mathrm{P}_{1}=$ green, $\mathrm{P}_{2}=$ brownish green, $\mathrm{P}_{3}=$ brown, and $\mathrm{P}_{4}=$ black. Each treatment has four replications so that there are 16 treatments in this study. The seeds of Indigofera were harvested from the experimental field of Indonesian Goat Research Station. The pods were separated based on the colour; ie: green, brownish green, brown, and black pod. Each colour of pod was taken as many as 100 pod twigs for observation. The variables measured were as follow:

\section{Characteristics and morphology of pods and seeds of Indigofera}

Characteristics observed in this study were:

1. Number of pods. One hundred pods were obtained from separation of pods and twigs

2. An average number of pods/twigs

3. Fresh weight of pods by weighing the pods obtained from each group of pod colour

4. The dry weight of pods. The obtained pods were dried in the sun for three days and weighed

5. Percentage of pod dry weight
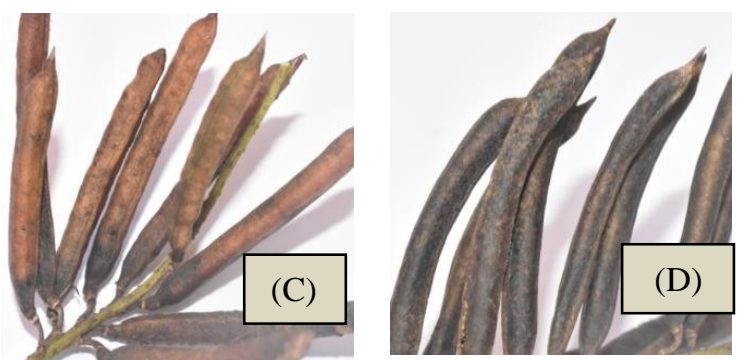

(A): Green pod; (B): brownish green pod; (C): Brown pod; (D): Black pod

Figure 1. Indigofera pod colour performance. 
6. Length of the pod. There were as many as 50 fresh pods, were measured between one tip to the other tip of pod with ruler

7. The diameter of the pod was measured by means of round pods using the yarn then the yarn was measured using ruler

8. A number of pods attacked by pests. A total of 50 fresh pods were observed for its pest attacks marked by the presence of holes in pods

9. A total number of seeds. The dried pods were milled using a blender, then sieved and cleaned and then calculated the number of seeds obtained

10. Seed weight. The seeds obtained were weighed

11. A number of seeds/pods. A number of seeds in one gram was then counted

12. The shape of round and flat seed. As many as one gram of seeds were separated based on the shapes of the round and flat

\section{The sprout growth of Indigofera seeds}

The Indigofera seed sprout test was performed in the laboratory using materials such as petri dish, measuring cup, gas stove (heater), thermometer, water and cotton. The seeds obtained from each group of color were sprout growth test. The seeds of Indigofera were soaked in a glass with a temperature of $100^{\circ} \mathrm{C}$ and left for one night (12 hours), and then the water was drained. The seeds were sowed on wet cotton laid in a bottom of a petri dish. Each group of pod color consisted of 100 tested seeds multiplied by four replications. Sprout growth was observed from 3 to 20 days after seeding.

The parameters observed were:

a. The growth of sprout (Gos)

The growth of sprout was measured by counting the number of sprouts growing on the 20th day, which was estimated no more sprouts were growing, then calculated the percentage of sprouts growing with the formula:

$$
\text { Gos }=\frac{\sum \text { sprouts } \times 100 \%}{\sum \text { Total seeds planted }}
$$

b. The weight of sprouts

The weight of the sprouts was obtained by collecting all the growing sprouts, then weighed using the electric scales capacity of $125 \mathrm{~g}$. Furthermore, the weight obtained divided by the number of sprouts.

c. The measurement of sprouts

The measured Indigofera sprouts by the root primer length and the height of the sprouts using a measuring instrument (ruler). Primary root length measurements start from the beginning to the tip root, while the height of the sprouts is measured from the base to the tip of the sprouts.

d. The number of sprout leaves

To obtain the number of sprout leaves (Nos) was done by the formula:

$$
\text { Nos }=\frac{\sum \text { sprout of leaves }}{\sum \text { growing sprouts }}
$$

\section{The growth of fungus (Gof)}

The growth of fungus in Indigofera sprout could be seen with nacked-eyes (macroscopic). Symptoms that appear were a fungus characterized by the existence of white hyphae threads and black spots (Meilan et al. 2014). The appearance of fungal colonies at the time of seed germination was calculated by the following formula:

$$
\text { Gof }=\frac{\Sigma \text { the growth of fungus } \times 100 \%}{\Sigma \text { planted seeds }}
$$
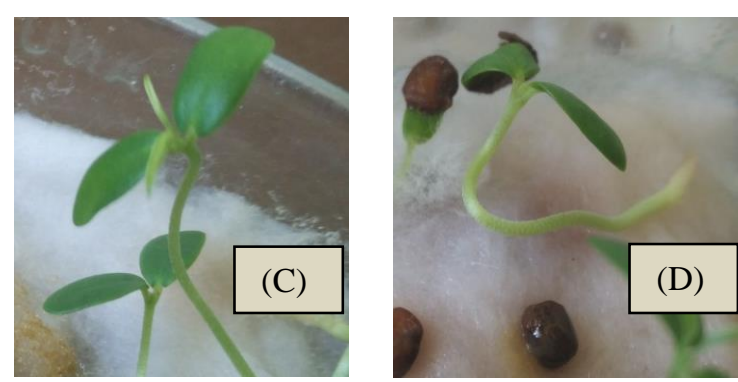

(A): Sprouts from the green pods; (B): Sprouts from the brownish green podst; (C): Sprouts from the brown pods; (D): Sprouts from the black pods

Figure 2. Sprouting performance of Indigofera seeds selected from four groups of pod color. 


\section{Statistical analysis}

The data obtained were analyzed with a linear model using SAS software (2009). Significant differences among treatment means were tested using Duncan's multiple range test (DMRT) at the 5\% level of.

\section{RESULTS AND DISCUSSION}

\section{Characteristics and morphology of pods and seeds of Indigofera}

The morphological and characteristics of several phases of the pods and seeds of Indigofera are presented in Table 1. One hundred twigs of samples in each pod colour used in this observation, the number of pods obtained from green, brownish green, brown and black were 1784, 1676, 1394, and 997 pods, respectively. The highest number of seed was found in green pods, and the lowest was detected in the black pod. The data of fresh weight and dry weight of pod seeds showed that although the fresh weight was higher $(18.70 \mathrm{~g})$ in the green pod, however the dry weight of seeds obtained was very low $(26.20 \%)$ indicating that the seeds contained high moisture inside the pods. Although, the black pod colour has the lowest weight (300 g), but the percentage of dry weight obtained was quite high
(86.67\%). The average diameter pod $(4.32 \mathrm{~mm})$, almost the same for all treatments. The longest pod was green pods $(36.43 \mathrm{~mm})$ and the shortest was in brown colour $(33.5 \mathrm{~mm})$. The largest pod diameter $(4.6 \mathrm{~mm})$ was in brownish green colour, while the smallest were $4.15 \mathrm{~mm}$ found in black colour pods. The number of pods affected by pests was mostly found in black pod (49\%) and the lowest was detected in brownish green (14\%) indicating that the black pod colour has been attacked by some pests.

This was most likely because the time for green pod to become black pod took about two months, which was plenty of time for pests to grow and damage the pods. While the green pod formation only took about a month which was less time to be damaged by the pest.

Observations on seed production, green pod colour had the highest number of seeds $(5,173)$, weighing $20.3 \mathrm{~g}$, while the brownish green pods had 4,944 seeds, with total weigh of seeds was $24.24 \mathrm{~g}$. The lowest number of seeds were in brown and black pods of 3,792, and 3,589 seeds, weighing 23.09 and $18.99 \mathrm{~g}$, respectively. The number of seeds/pods of each colour was moderate and nearly same (average 3.07); the highest (3.6) in the black pods and the lowest (2.9) in the green. The number of seeds/g was mostly in green pods (252) and brownish green (204), less in brown (172) and black (189). The shape of round seeds was the highest $(73 \%)$ in brownish green while the flat shape was the highest $(53 \%)$ in green pod.

Table 1. The characteristics morphology of pod and seed of Indigofera

\begin{tabular}{lccccc}
\hline \multirow{2}{*}{ Parameters } & \multicolumn{3}{c}{ The colour of pods } & Average \\
\cline { 2 - 4 } & Green & Brownish green & Brown & Black & 1462.75 \\
Number of pod & 1784 & 1676 & 1394 & 997 & 14.63 \\
Average of pod/twig & 17.84 & 16.76 & 13.94 & 9.97 & 807 \\
Fresh of pod weight (g) & 1870 & 590 & 470 & 300 & 347.50 \\
Dry weight (g) & 490 & 300 & 340 & 260 & 59.01 \\
Dry weight (\%) & 26.20 & 50.85 & 72.34 & 86.67 & 3479 \\
Length of pod (mm) & 36.43 & 34.92 & 33,5 & 34.33 & 4.32 \\
Diameter of pod (mm) & 4.3 & 4.6 & 4.25 & 4.15 & 28.5 \\
Pods attacked by pests (\%) & 22 & 14 & 29 & 49 & 4419 \\
The total number of seeds & 5173 & 4944 & 3972 & 3589 & 21.71 \\
The weight of seeds (g) & 20.53 & 24.24 & 23.09 & 18.99 & 204.25 \\
Number of seeds/g & 252 & 204 & 172 & 189 & 3.07 \\
Average of seeds/pod & 2.9 & 2.95 & 2.85 & 3.6 & 62.5 \\
Round seeds (\%) & 47 & 73 & 67 & 63 & 37.5 \\
Flat seeds (\%) & 53 & 27 & 33 & 37 & \\
\hline
\end{tabular}




\section{The sprout growth of Indigofera seeds}

The results of the study to the sprout growth of Indigofera seed are shown in Table 2 . The average percentage of the sprout growth was $57.75 \%$. The highest percentage $(\mathrm{P}<0.05)$ was found in brownish green pod $(62 \%)$. Sprout growth was lower than the normal standard. According to the Directorate General of Food Crops (1991), the standard (SNI = Indonesian National Standard) of seed that was able to sprout should be minimum $75 \%$ and the plant should be able to grow normal under suboptimum conditions. The weight of sprout was significantly $(\mathrm{P}<0.05)$ the heaviest $(0.035$ g) from the seeds in brownish green pods, compared to those in the other pod colours, indicating that the plant would grow strong.

The average heights of sprouts are $2.68 \mathrm{~cm}$, a range of $2.35 \mathrm{~cm}$ (green) $-3.18 \mathrm{~cm}$ (black). The height of sprouts from black pod was significantly different $(\mathrm{P}<0.05)$ from three other colours, indicating that they would have the higher growth and production (Risva et al. 2014).

Primary root length showed that the seeds from brownish green, brown, and black were relatively same and did not differ significantly, achieving of length of $1.67,1.74$, and $1.68 \mathrm{~cm}$ respectively; they were significantly longer $(\mathrm{P}<0.05)$ than that of seeds obtained from the green colour $(1.42 \mathrm{~cm})$. The length of the root of all sprouts of seeds from previous three colors could spur the growth of plants and increase the ability to absorb water and dissolved nutrients (Hidayanto et al.
2003; Nio \& Patricia 2013).

The average number of sprout leaves of seeds obtained from brownish green, brown, and black pods did not differ significantly $(\mathrm{P}<0.05)$. While the average number of leaves counted from seeds derived from green pods was the lowest $(1.61 \mathrm{~cm})$. This was most likely due to the low content of gibberellin in young seeds indicating that the growth of the content of the seed substance was still low. Weiss \& Ori (2007) reported that one of the physiological effects of gibberellin was to encourage the activity of hydrolytic enzymes in seed germination processes.

The growth of sprouts according to the shape of Indigofera seeds is shown in Table 3. The results obtained indicate that the shape of the seed does not affect seed germination. However, it has a significant effect on the height of sprout, length primary root, and number of leaves. Round seed growth is superior compared to the flat, has the highest germination (3.12 $\mathrm{cm}$ ), the primary root length was $2.02 \mathrm{~cm}$, and the number of leaves of 2.14 strands. There was significantly different $(\mathrm{P}<0.05)$ to the growth of flat seeds $(2.15 \mathrm{~cm}, 1.23 \mathrm{~cm}$ and 1,6 strands) respectively. The high levels of growth of sprout in the round seeds is agreement with previous reports (Gusta et al. 2003), on Maize seedlings showed that the types of round seed was higher in growth rate than the flat one. This is most likely due to the cotyledon of the round seeds was wider, so that the photosynthetic potential is higher than the flat seeds.

Table 2. The growth of sprouts of Indigofera seeds from four different colour of pod

\begin{tabular}{|c|c|c|c|c|c|}
\hline \multirow{2}{*}{ Parameter } & \multicolumn{4}{|c|}{ The colour of pods } & \multirow{2}{*}{ Average } \\
\hline & Green & Brownish green & Brown & Black & \\
\hline Growth of sprouts (\%) & $55^{\mathrm{b}}$ & $62^{a}$ & $57^{b}$ & $45^{\mathrm{c}}$ & 57.75 \\
\hline Weight of Sprouts (g) & $0.024^{\mathrm{d}}$ & $0.035^{\mathrm{a}}$ & $0.032^{\mathrm{b}}$ & $0.030^{\mathrm{c}}$ & 0.030 \\
\hline Height of sprout (cm) & $2.37^{\mathrm{c}}$ & $2.35^{\mathrm{c}}$ & $2.81^{\mathrm{b}}$ & $3.18^{\mathrm{a}}$ & 2.68 \\
\hline Length of primary root $(\mathrm{cm})$ & $1.42^{\mathrm{b}}$ & $1.67^{\mathrm{a}}$ & $1.74^{\mathrm{a}}$ & $1.68^{\mathrm{a}}$ & 1.63 \\
\hline Number of leaves (strands, cm) & $1.61^{\mathrm{c}}$ & $1.81^{\mathrm{a}}$ & $1.82^{\mathrm{a}}$ & $1.75^{\mathrm{a}}$ & 1.75 \\
\hline
\end{tabular}

Values with different superscripts are significantly different $(\mathrm{P}<0.05)$

Table 3. The growth of sprouts of Indigofera seeds based on different shape

\begin{tabular}{lcc}
\hline \hline & & The shape of seed \\
\cline { 2 - 3 } Parameter & Round seeds & Flat seeds \\
\hline Growth of sprout $(\%)$ & $59.76^{\mathrm{a}}$ & $54.84^{\mathrm{a}}$ \\
Height of sprout (cm) & $3.12^{\mathrm{a}}$ & $2.15^{\mathrm{b}}$ \\
Length of primary root (cm) & $2.02^{\mathrm{a}}$ & $1.23^{\mathrm{b}}$ \\
Number of leaves (strands) & $2.14^{\mathrm{a}}$ & $1.6^{\mathrm{b}}$ \\
\hline
\end{tabular}

Values with different superscripts are significantly different $(\mathrm{P}<0.05)$ 


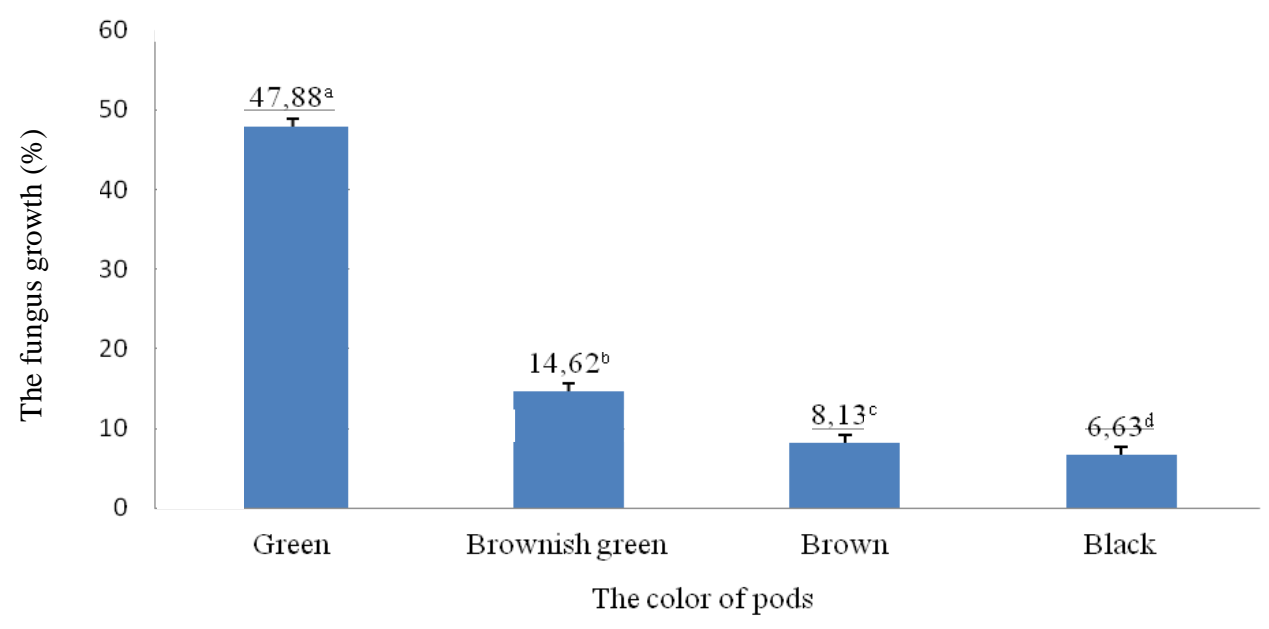

Figure 3. The fungus growth from different pod colour.

In Figure 3, it is shown that the darker of pod colour has the lower growth of the fungus. The lowest number of fungi was from black pod colour seeds which was only $6.63 \%(\mathrm{P}<0.05)$ compared to the other three pod colours $(8.13 \%, 14.62 \%$, and $47.88 \%$, respectively). This was most likely related to the water content of each colour phase. In tune with the dry matter content of the seeds in Table 1 the highest water content was found in green pod, and slightly present in black. The higher the moisture content is, the more fungi growth. It was suggested by Suryanto (2013), that water content in seed should be controlled to be as low as $10.82 \%$ to get germination up to $71 \%$.

\section{The fungus growth}

Fungi are the main pathogenic causes of seed damage. Some fungi in seeds such as Alternaria sp, Fusarium oxysporum, $F$. solani, $F$. equiseti, Myrothecium roridum, Drechslera sp, are the most dangerous pathogen causing pathogenic disease since they depressed the health of plant (Bakr \& Rahman 2001). The low water content in seeds could inhibit fungal growth, and high water content caused high humidity. This condition could stimulate the growth of fungus during storage (Sudir et al. 2014). The moisture may induce fungi- airborne pathogens which contaminate the Indigofera seeds as well as the emergence of fungal colonies at the time of seed germination

\section{CONCLUSION}

The brownish green pod color of Indigofera zollingeriana seeds is well used against sprout growth, sprout weight, primary root length. While the black color of the pods has the least fungal growth.

\section{REFERENCES}

Al-Bugg YSH. 2017. Seeds, pods and petiole gland's characteristics of Leucaena spp. analytical study (a). Int J Res-Granthaalayah. 5:421-434.

Abdullah L. 2014. Prospektif agronomi dan ekofisiologi Indigofera zollingeriana sebagai tanaman penghasil hijauan pakan berkualitas tinggi. Pastura. 3:79-83.

Bakr MA, Rahman ML. 1998. Current status of research on mungbean and black gram diseases and future needs. Proceeding of the workshop on diseases resistance breeding in pulse. Bangladesh J Agric. 11:64-72.

Directorate General of Food Crops. 1991. Petunjuk Pengawas Benih. Jakarta (Indones): Direktorat Jendral Pertanian Tanaman Pangan - Direktorat Bina Produksi Padi dan Palawija Sub Direktorat pengawasan Mutu dan Sertifikasi Benih.

Effowe, TQ, Amevoin K, Nuto Y, Mondedji D, Glitho IA. 2010. Reproductive capacities and develop ment of a seed bruchid beetle, Acanthocelides macrophthalmus, a potential host for the mass rearing of the parasitoid, Dinarmus basalis. J Insect Sci. 10:129-136.

Ernestina F. 2003. Pengaruh fase perkembangan polong dan trikoma terhadap preferensi penularan hama penggerek polong kedelai Etiella zinkenella treit. [Skripsi]. [Malang (Indonesia)]: Fakultas Pertanian, Universitas Brawijaya.

Girsang RC. 2012. Viabilitas Benih Indigofera (Indigofera zollingeriana) setelah Injeksi Karbon Dioksida (CO2) dan Penyimpanan [Skripsi]. [Bogor (Indonesia)]: Institut Pertanian Bogor.

Gomes J, Bayer C, De Souza Costa F, De Cássia Piccolo M, Zanatta JA, Vieira FCB, Six J. 2009. Soil nitrous oxide emissions in long-term cover crops-based rotations under subtropical climate. Soil Tillage Res. 106:36-44. 
Gusta LV, Johnson EN, Nesbit NT, Kirkland KJ. 2003. Effect of seeding date on Canola seed vigor. Can J Plant Sci. 45:32-39.

Harnowo D. 2015. Prinsip-prinsip produksi benih kedelai. In: Didik H, Marwoto, Muchlish A, Titik S, Novita N., editors. Malang (Indones): Balai Penelitian Tanaman Aneka Kacang dan Umbi. p. 10-13.

Hindun, Wicaksana N, Waluyo B, Rachmadi M, Karuniawan A. 2013. Karakteristik fisik polong dan biji kacang bambara (Vigna subterranea (L). Verdc.). Budi W, Agung K, Noladhi W, editors. Prosiding Seminar Nasional 3 in one Malang. Malang (Indones): Fakultas Pertanian, Universitas Brawijaya. p. 430-435.

Hidayanto M, Siti N, Yossita F. 2003. Pengaruh panjang stek akar dan konsentrasi natrium nitrofenol terhadap pertumbuhan stek akar sukun. J Pengkajian dan Pengembangan Teknologi Pertanian. 6:154-160.

Hutasoit R, Riyadi, Ginting SP. 2017. Pengaruh suhu perendaman terhadap pertumbuhan kecambah benih Indigofera zollingeriana. Puastuti W, Muharsini S, Inounu I, Tiesnamurti B, Kusumaningtyas E, Wina E, Herawati T, Hartati, Hutasoit R, et al., editors. Prosiding Seminar Nasional Teknologi Peternakan dan Veteriner. Bogor (Indones): Pusat Penelitian dan Pengembangan Peternakan. p. 531-538.

Kissock DC, Haferkampa MR. 1983. Presowing seed treatment and temperature effects on germination of Engezmannia pinnatifida and Indigofera miniata var.leptosepala. J Range Manag. 36:94-97.

Meilan S, Azis P, Sulandari S. 2014. Pengaruh pemanasan terhadap perkecambahan dan kesehatan benih kedelai (Glycine max (L.) Merrill). J Vegetalika. 3:27-37.

Nio SA, Patricia T. 2013. Karakter morfologi akar sebagai indikator kekurangan air pada tanaman. J Bioslogos. 3:32-39.
Rahmawathi AM. 2017. Sistem agroforestri sentang (Azadirachta excelsa (jack) m. jacobs) dengan kedelai (Glycine max (1.) merr.) secara organik. [Thesis]. [Bogor (Indones)]: Institut Pertanian Bogor.

Risva AH, Tohari, Sri NHU. 2014. Takaran pupuk nitrogen dan silika terhadap pertumbuhan awal (Saccharum officinarum L.) pada inceptisol. Vegetalika. 3:35-44.

SAS Institute Inc. 2009. SAS/STAT 9.2 User's Guide. Cary, NC (USA): SAS Inst Inc.

Salvador I de S, Medeiros RMT, Pessoa CRM, Dantas AFM, Júnior GS, Riet-Correa F. 2010. Intoxicação por Indigofera suffruticosa (Leg. Papilionoideae) em bovinos. Pesqui Vet Bras.

Sudir, Nasution A, Santoso, Nuryanto B. 2014. Penyakit Blas Pyricularia grisea pada tanaman padi dan strategi pengendaliannya. Iptek Tanaman Pangan. 9:85-96.

Suharlina, Dewi A, Nahrowi, Jayanegara A, Abdullah L. 2016. Nutritional evaluation of dairy goat rations containing Indigofera zollingeriana by using in vitro Rumen Fermentation Technique (RUSITEC). Int $\mathrm{J}$ Dairy Sci. 11:100-105.

Suryanto H. 2013. Pengaruh beberapa perlakuan penyimpanan terhadap perkecambahan benih suren (Toona sureni) (effects of storage of suren (Toona sureni) seeds on germination). J Pen Kehut Wallacea. 2:26-40.

Telleng M, Wiryawan KG, Karti PDMH, Permana IG, Abdullah L. 2017. Silage quality of rations based on in situ sorghum-indigofera. Pak J Nutr. 16:168-174.

Weiss D, Ori N. 2007. Mechanisms of cross talk between gibberellin and other hormones. Plant Physiol. 144:1240-1246.

Winata, Nash, Karno, Sutarno. 2012. Pertumbuhan dan produksi hijauan gamal (Gliricidia sepium) dengan berbagai dosis pupuk organik cair. Anim Agric J. 1:797807. 